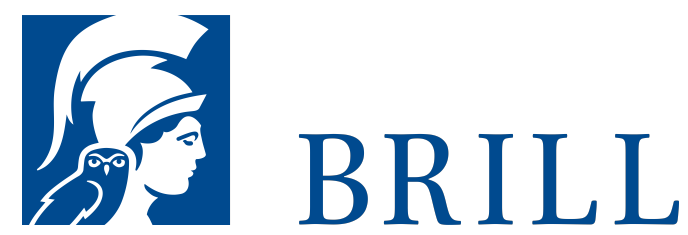

\title{
Ethik der Finanzmarktrisiken am Beispiel des Finanzderivatehandels
}

\section{Author: Simone Heinemann}

Ethische Fragen der Finanzmärkte werden immer intensiver diskutiert. Die Risiken auf Finanzmärkten sind dagegen aus ethischer Perspektive nahezu unbeachtet geblieben. Gerade angesichts der Finanz- und Wirtschaftskrise ab 2007 und aktueller Regulationsanstrengungen ist es jedoch dringlicher denn je, ethische Überlegungen anzustellen, um geeignete Kriterien für einen verantwortungsvollen Umgang mit Risiken zu finden. Die Autorin entwickelt in diesem Buch erstmals eine Risikoethik für den Finanzmarkt. Sie zeigt auf, dass sich aus beiden Hauptansätzen der normativen Ethik, dem Utilitarismus und den rechtebasierten Theorien Kriterien für einen moralisch akzeptablen Umgang mit Finanzmarktrisiken gewinnen lassen. Die Analyse erfolgt explorativ am Beispiel des Handels mit Finanzderivaten, die nützliche, aber auch 'gefährliche' Mechanismen zur Risikoübertragung und -verteilung auf Finanzmärkten bereitstellen. Im Rückgriff auf die erarbeiteten Kriterien legt die Untersuchung die risikoethischen Probleme des Finanzderivatehandels frei und beleuchtet die ethische Dimension systemischer Finanzmarktrisiken.

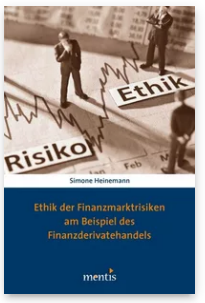

Pages: 272

Seiten

Language:

German

Subjects:

General,

Philosophy

Publisher: Brill | mentis

E-Book (PDF)

Released online: 18 Mar 2014

ISBN: $978-3^{-}$ 89785-906-7

List price

Paperback

Publication date: 18 Mar 2014

ISBN: 978-389785-632-5 List price 
For more information see brill.com

Order information: Order online at brill.com +44330 333 0049 | customerservices@brill.com Submission information: brill.com/authors

Titles published by Brill | Fink, Brill | mentis or Brill | Schöningh: +49(o)715413279216| brill@brocom.de 